\title{
ROLE OF HAJJ AND UMRAH (PILGRIMAGE TOURISM) IN SAUDI ARABIAN ECONOMY
}

\author{
ALI A. ALALMAI ${ }^{1}$ A. ARUN ${ }^{2}$ \& MOHD AARIF \\ ${ }^{I}$ Assistant Professor, Community College, Jazan University, Saudi Arabia
}

${ }^{2}$ Assistant Professor, School of Hotel and Catering Management, Vels Institute of Science Technology and Advanced Studies (VISTAS), Chennai, India

${ }^{3} J J T$ University, Jhunjhunu, India

\begin{abstract}
In Makkah, the pilgrims in Hajj and Umrah are major centers of economic development, with millions of Muslims traveling every year to holy cities. In the development of the first mosque in the world, Prophet Mohammed (saw) played an important role in the mosque of Quba. Masjid Al Haram, the world's largest mosque, is in Makkah and is the home of the Kabba, the most sacred Muslim sanctuary in the world. As one of the five pillars of Islam, all physical and financially competent Muslims must take part in their pilgrimage at least once in their lives.
\end{abstract}

KEYWORDS: Hajj, Umrah, Mekkah, Saudi Araiba

Received: Aug 06, 2020; Accepted: Aug 26, 2020; Published: Nov 23, 2020; Paper Id.: IJMPERDOCT202066

\section{INTRODUCTION}

Hajj is the fifth pillar of Islam, an obligation on every able-bodied Muslim who can afford to do it; a journey with rites that must be performed at a certain time, in a certain way. Tourism in Saudi Arabia is largely based around religious pilgrimage. Mecca receives over three to four million pilgrims a year during the month of Dhu al-Hijjah in Hajj, and around two million during the month of Ramadan in Umrah. ${ }^{1}$ During the rest of the year, Mecca receives around four million for Umrah. According to the World Bank, approximately 64.7 million people visited Saudi Arabia in 2017-18, making it the world's $12^{\text {th }}$ most-visited country. Saudi Arabia's overall number of tourist trips is on course to hit 93.8 million by $2023 .{ }^{2}$ The potential tourist areas of Saudi Arabia also includes the Hijaz and Sarawat Mountains, Red Sea diving and a number of ancient ruins.

\section{Contribution in National Economy}

A major change occurred in the economy of Kingdom of Saudi Arabia (KSA) after discovery of oil. Prior to that, the KSA economy, particularly of the two holy cities of Mecca and Medina and places en-route was depended overwhelmingly on Hajj. Now, the dependence has reduced. However, the role of Hajj in the economy is significant even today. According to a field study, the monetary value of activities related to the Hajj and Umrah exceeds $\$ 80$ billion. Hajj revenues poised to exceed $\$ 150$ bn by 2022 . The importance of emergence of Umrah in the economy can be understood by the fact that it is estimated that its revenue is marginally more than that from Hajj, of the 60 million pilgrims visiting Saudi Arabia every year, the number of Hajj visitors is just over 25 to 30 million. Even today, the number of tourists is still only a fraction of the world's Muslim population of 1.8 billion, with a year-on-year growth of $6.7 \%$. Unlike the Hajj, Umrah can be performed at any time, though it is particularly 
popular during the fasting month of Ramadan. (These figures are, at best, estimates because there is no authentic basis of collection, reporting and analysis of data. There is dearth, if not unavailability of published figures of revenues generated by Hajj either.) The revenue from Hajj includes rent that the building owners charge in Mecca and Medina in the pilgrimage seasons. Transport sector including cross-border transport is another major revenue generator. Pilgrims tend to buy gifts and mementos as well. All this benefits the host country. Perhaps no country in the world can match the revenue generated by tourism as in KSA. It is estimated that Hajj and Umrah taken together contribute more than 20 per cent of non-oil Gross Development Product (GDP) of the Kingdom. It is further estimated that this income comprises about seven per cent of the KSA's total GDP. To be sure, the statistics reflect the multiplier effect on the economy, as every riyal spent brings about four additional riyals. Business reports conclude that Saudi tourism, especially the religious variety, is recession proof.

\section{Employment Generation}

Tourism is one of the biggest industries worldwide, responsible for a large amount of employment across nation. This is very much the case in Saudi Arabia, where latest research predicts nearly 1.8 million people will work in the industry by 2020, almost tripling 2015 figures. The Saudi Arabian Monetary Agency (SAMA) report says employees in the tourism sector would rapidly increase from the 670,000 jobs in 2011, a 5.9 percent increase on 2010. Tourism jobs accounted for 7.6 percent of the total workers of $8.8 \mathrm{~m}$ in 2011 , and were forecast to rise to 9.7 percent. "We expect the sector would provide 841,000 direct jobs and 421,000 indirect jobs by 2015 and 1.2m direct jobs and 591,000 indirect jobs by 2020," the report said.

The Saudi economy needs to generate more than 260,000 jobs a year to cope with demand. Hajj provides employment opportunities for the citizens of KSA and most of the Hajj related services can be performed without any special requirement of specific skills. In addition to the Saudi citizens, Hajj provides ample employment opportunities to non- Saudi residents as well.

\section{Infrastructure and Logistics Development}

The infrastructure demands linked to the Hajj are enormous. From investment in airport facilities (e.g. an additional terminal for the Hajj season) to the need for roads and tunnels to procuring fleets of buses transporting pilgrims, facilitating the Hajj requires significant infrastructure. On top of this physical infrastructure, the logistics of managing the flow of people, water, food, electricity, and other utilities are daunting.

A major source of mass employment is the development of infrastructure and construction. The Saudi government has been developing Hajj facilities in a grand manner. Its continuing and future development plans are ambitious enough to ensure continued employment. Changing Mecca's landscape with heavy construction plans, construction of mono rails connecting Mecca, Mina, Mudalifa and Arafat - the places where the pilgrims move during Hajj rituals - Railway projects for joining different cities of the Kingdom including Mecca and Medina, revival of Hajjaz railway for facilitating pilgrims from Turkey, etc are in the pipeline.

Institutions involved in Hajj infrastructure and logistics have developed a set of skills and competencies that are immensely valuable. Creatively leveraging, replicating, and applying those skills in a broader range of ventures represents a unique opportunity for such institutions and for the Saudi Arabian economy at large. 


\section{Promotion of Trade and Industry}

The sources attributed the increase in revenues to the high Hajj fees and cost of living, which had a positive impact on the service sectors, including hotels, money exchange and retail shops, communications and restaurants in the cities of the western region, especially Mecca and Medina. Despite the large Hajj and Umrah market, the sale of Saudi products including gift items was low. Handicrafts of Saudi productive families lacked marketing channels required for its success. Saudi gift items are facing big competition from Chinese products. There is need for strengthening the capabilities of young Saudi men and women in making innovative gift items with a Makkah and Madinah touch for sale among pilgrims and other visitors. Saudi products could make revenue of SR 500 million to SR 800 million annually if properly marketed. Small and medium enterprises to produce gift items to market among pilgrims are potential area for young Saudi entrepreneurs to enter and progress. It can also create more jobs for Saudis.

\section{Future Prospect}

Saudi Arabia is working on developing its tourism industry, with a number of hotels being built to cater to the needs of future tourists. The objective of this increasing supply of hotel rooms is to boost the country's tourism and attract travelers from different countries around the world. The investment into hotels in turn means the creation of direct and indirect jobs in the near future. Therefore, along with the growth and investment into Saudi Arabian tourism, an increasing number of people will be able to gain employment within the industry.

\section{Recent Major Steps Taken by the Saudi Govt. in Development of Tourism}

The Government of Saudi Arabia has nowadays understood the importance in promotion of the tourism many valuable remedial actions has been taken to improve the tourism in the nation domestically and internationally. A full swing operation has been done in developing the countries infrastructural facilities in and around the famous tourism destinations. a

The Country has established an organization called Saudi Commission for Tourism and Antiquities, the organization main role is to develop the county in tourism prospects. This organization plays an active role in the destination marketing of the nation. They promote the investment in the tourism sector in attracting the visitors to the nation. ${ }^{\text {b }}$

National Tourism Development Strategy is a set of practice recommended and developed in two phase by the Saudi Commission for Tourism and Antiquities, they involve in developing the tourism at Saudi Arabia staying consistent in following the ethical rules and regulation of the religious facts and procedures. The strategies framed were well organized and content enough to adhere for the next twenty years. ${ }^{\mathrm{c}}$

The country's representative have signed an understand memorandum with Saudi Arabian General Investment Authority highlighting essential points investing about SAR 37.5 billion to develop the tourism, hospitality and entertainment activities throughout the nation. ${ }^{\mathrm{d}}$

The restrictions in the country for the foreign visitors have been more relived to promote the foreigners visit to the nation. The SCTH of Saudi Arabia plans to improve the travel and tourism from the foreign countries as in 2016 about 18 million people visited for the pilgrimage. The organization plans to promote tourism with developing the famous monuments, archeological sites into the tourism packages. ${ }^{\mathrm{e}}$ 


\section{CONCLUSIONS}

Saudi Arabia is the country with a rich values of morals and religious importance has been the dwelling for ethical importance in belief. The nation has many rich resources boosting the economic aspects besides the country also portrayed for the pilgrimage importance, it develops many policies and procedures in developing the tourism necessities to enhance the tourist visitors nationally and internationally. Being economically benefited by the pilgrimage tourism, the country also concentrates in developing the need and requirements of the tourist visiting the nation. It develops many strategic plans to develop the tourism and provide a satisfied travel for the tourist.

\section{REFERENCES}

1. Daniel Moshashai \& Rachna Uppal. Tourism as a pillar of the new Saudi Arabia. Updated 2019 December 3 [Internet] Cited on 2020 June 3 Available from: https://castlereagh.net/tourism-as-a-pillar-of-the-new-saudi-arabia/

2. Mourad Mansour and Alhassan G Mumun. Motivations and attitudes toward domestic tourism in Saudi Arabia. European Journal of Tourism, Hospitality and Recreation | Volume 9: Issue 1. DOI: https://doi.org/10.2478/ejthr-2019-0004

3. Tourism Investment in Saudi Arabia Report [Internet] Available from: https://mt.gov.sa/en/TourismInvestment/SupportTourismInvestment/Documents/Touristic_investment_eng.pdf

4. Vicky Karantzavelou. Vision 2030 Plan aims to make Saudi Arabia a top five global destination. Updated 2019 October 1 [Internet] Cited on 2020 May 28. Available from: https://www.traveldailynews.com/post/vision-2030-plan-aims-to-makesaudi-arabia-a-top-five-global-destination

5. Ghazanfar Ali Khan. Saudi Arabia launches new tourism initiatives within Vision 2030. Updated 2017 July 17. [Internet] Cited on 2020 June 1 Available from https://www.arabnews.com/node/1130646/saudi-arabia

6. Alghamdi, A. (2007) Explicit and Implicit Motivation towards Outbound Tourism: A Study of Saudi Tourists, Unpublished doctoral thesis, School of Business and Management, University of Glasgow, Glasgow: UK.

7. Ali, R., Clampet, J., Schaal, D. and Shankman, S. (2014) 'The 14 trends that will define travel in 2014', Available at http://skift.com/travel-trends/14-global-trends-that-will-define-travel-in-2014/(accessed 20 June 2014).

8. Alsini, I. and Ekiz, H. E. (2013) 'Saudi Arabia: A great potential for Chinese hoteliers', China Tourism and China HotelBranding Forum 2013. 16th - 18th May, UNWTO, Hong Kong Polytechnic University, Hong Kong.

9. BBC (2013) 'Suadi Arabistan'in turizm hamlesi', in BBC Turkish, 15 May 2013, Available at http://www.bbc.co.uk/turkce/multimedya/2013/05/130515_biz_suudi_turizm.shtml (accessed 8 May 2014).

10. Arabnews (2014) 'Saudi GDP per capita estimated at \$26,000', Online Newspaper, Available at http://www.arabnews.com/news/583751, (accessed 8 May 2014).

11. Badone, E. and Roseman, S. R. (2004) Intersecting Journeys: The Anthropology of Pilgrimage and Tourism, Illinois: University of Illinois Press.

12. Battour, M. M., Battor, M. M. and Ismail, M. (2011) 'The impact of destination attributes on Muslim tourist's choice', International Journal of Tourism Research, 13(6): 527-540.

13. Battour, M. M., Battor, M. M. and Ismail, M. (2012) 'The mediating role of tourist satisfaction: A study of Muslim tourists in Malaysia', Journal of Travel and Tourism Marketing, 29(3): 279-297.

14. Bhardwaj, S. (1998) 'Non-Hajj pilgrimage in Islam: A neglected dimension of religious circulation', Journal of Cultural Geography, 17(2): 69-87. 
15. Burns, P. (2007) 'From Hajj to hedonism? Paradoxes of developing tourism in Saudi Arabia', R.F. Daher (eds), Tourism in the Middle East: Continuity, Change, Transformation, Clevedon: Channel View Publications, 215-236.

16. Daher, R. (2007) Reconceptualizing tourism in the Middle East: Place, heritage, mobility and competitiveness, R. Daher (eds), Tourism in the Middle East: Continuity, Change, \& Transformation, Clevedon: Channel View Press, pp. 1-69.

17. Din, K. H. (1989) 'Islam and tourism: Patterns, issues, and options', Annals of Tourism Research, 16(4): 542-563.

18. Eid, R. (2012) 'Towards a high-quality religious tourism marketing: The case of Hajj service in Saudi Arabia', Tourism Analysis, 17(4): 509-522.

19. GASME (2014) 'Brief Introduction of Saudi Arabia', The Global Alliance of Small and Medium-Sized Enterprises, Available at http://www.globalsmes.org/news/index.php?func $=$ detail\&detailid $=1061 \&$ catalog $=20 \& l a n=e n \& s e a r c h \_k e y w o r d s=$ (accessed 21 June 2014).

20. GCC-SG (2013) 'About the Cooperation Council for the Arab States of the Gulf-Secretariat' General, Available at http://www.gcc-sg.org/eng/indexc64c.html?action=GCC (accessed 1 June 2014). 

